The Culture of Cities

By Lewis Mumford. (London: Martin Secker and Warburg, Ltd., 1938.) 21s. net.

NR. MUMFORD is a disciple of Patrick Geddes. VI In "The Culture of Cities" he applies the principles of his master to the problems of the aggregations of man as city-dweller. He follows the growth of the city community as it has developed in the past, and then sketches the ideal in an essay of constructive reform.

The greater part of his book-that is the first four chapters, covering some three hundred pages-is devoted to the description of the four types into which he classifies cities as examples of communal association, and analyses the various characteristics of each type, tracing their consequences as forces moulding the life and character of the citizen. Of these types, the first is the medieval, which, as the author points out, was never far divorced from the countryside; the second is the city of court and parade, such as Paris under the ancient regime; thirdly comes 'Coketown', the product of the growth of industrialism and the assemblage of some of the most degrading conditions in which man can exist; and lastly 'Megalopolis', the contemporary city of banking and finance.

In this examination of cities of the past and present, Mr. Mumford not only shows himself to be a keen critic and acute analytical thinker, but also he gives evidence of a wide and profitable experience of many men and cities, which he brings to bear rationally on his conception of the ideal in form in relation to the needs of human development. What may perhaps be regarded as the pivotal principle of his conception is the necessity of communal control of the land-a principle to which we seem to be approximating, but with, some may think, fatal deliberation.

\section{Wild Animals in Britain}

By Frances Pitt. (British Nature Library.) Pp. viii $+120+68$ plates. (London: B. T. Batsford, Ltd., 1938.) $8 s .6 d$. net.

7 HIS addition to the "British Nature Library" 1 is uniform in make-up with Seton Gordon's "Wild Birds of Britain" and Robert Gathorne-Hardy's "Wild Flowers in Britain", and it has attained the same standard of almost unique beauty of production and considerable usefulness.

But the team responsible for the book was almost bound to produce the gem that this is. It is now traditional that a Batsford book on any natural history topic is art and science combined to produce just the right thing. Most of the hundred photographs which adorn the text are by well-known Nature photographers, Millais's "Roe Deer" is reproduced as a frontispiece, and the coloured jacket is by John Nash, whose delightful colour lithographs and line drawings illuminate the companion volume "Wild Flowers in Britain".

The illustrations certainly form the perfect complement to the text of Miss Pitt, who needs no introduction as a writer on natural history subjects. Scarcely a naturalist could have missed reading at least one of her many books, and hundreds of thousands of lay readers must have been charmed by her articles in various periodicals and newspapers. Here, as in all her works, Miss Pitt bases her descriptions chiefly on personal observation, thus making the text not only reliable but also intimate and charming. Anecdote and story mingle with text description in such a way as to give a scientific study which also stimulates friendly feeling towards the lower animals.

The book is deserving of the success which we feel sure lies ahead of it.

\section{The Chemistry of Synthetic Surface Coatings}

By Dr. Wm. Krumbhaar. Pp. 200. (New York: Reinhold Publishing Corporation; London: Chapman and Hall, Ltd., 1937.) 20s. net.

$r$ HE chemist is penetrating quite far into the 1 paint industry, partly as the result of the introduction of synthetic materials, with the consequence that a good deal is known about such important subjects as the chemical reactions in the varnish kettle, driers, the surface chemistry of pigments and paints, and the physical chemistry of surface coating. These subjects form the headings of a practical little work by Dr. Krumbhaar, who is himself engaged in the industry in the United States, where the application of all sorts of new coating materials is very much encouraged. A pleasing feature of the book is a number of excellent descriptive photomicrographs.

The new knowledge has even reached the printing ink industry, where the traditional slow-drying linseed oil media are losing ground in favour of quicker drying vehicles based on synthetic resins : a useful chapter is allocated to these developments.

The book will be found both stimulating and informative.

\section{The Children of Tane}

Bird Life in New Zealand. By Mona Gordon. Pp. xii $+250+8$ plates. (London: J. M. Dent and Sons, Ltd. ; Christchurch : Whitcombe and Tombs, Ltd., 1938.) 10s. 6d. net.

7 HIS book is written in a slightly romantic vein, 1 making much play with Maori names; but it deals in an interesting manner with bird-life in New Zealand, particularly the forest avifauna and measures for its preservation. The clearance of woodlands has had a very serious effect on the native birds, and this has been aggravated by the introduction of alien species. Fortunately, several islands have been set aside as inviolable sanctuaries, although even on some of these great harm is being done to the vegetation by imported deer or goats.

Each sanctuary is described, with an account of its history and its present state. There are also chapters on such topics as the pollination of plants by birds, flightless birds, and migratory birds-under each of which heads New Zealand provides some remarkable examples. 